\title{
Development of commercial banks in Yunnan along with the "The Belt and Road"
}

\author{
Fupei Gong \\ International Business School \\ Yunnan University of Finance and Economics \\ Kunming, China \\ 3329479645@qq.com
}

Guiying Ma

Department of Education Audit

\author{
Yunnan Procincial Audit Office \\ Kunming, China \\ 541234631@qq.com
}

Xiaohong Cun*

International Business School

Yunnan University of Finance and Economics

Kunming, China

16990822@qq.com

\begin{abstract}
The Belt and Road" strategy is our country's opening up to achieve a strategic change, China's government lead and strongly promote the medium and long-term national strategy, in order to let more and more enterprises to go out, the Commercial Banks of cross-border financial service in the area along the way to carry out investment operations must be supported and protected. This paper mainly discusses the opportunities and challenges of the financial services "going out" of Yunnan Bank.
\end{abstract}

Key words - The Belt and Road; commercial bank; financial services

\section{INTRODUCTION}

"The Belt and Road" refers to Silk Road Economic Belt and twenty-first Century maritime Silk Road. "The Belt and Road" strategy is not a new mechanism, but it's still an idea and initiative for development. And this will rely on China and relevant countries' existing bilateral and multilateral mechanisms, then launch some facilitation measures, such as interoperability, the traffic infrastructure, trade and investment Relying on the "Silk Road" economic, cultural, trade and the Millennium heritage, and give it a new sense of cooperation. To build the "The Belt and Road", which is Chinese government committed to maintain the system of free trade system and open global economy, then promote the countries to strengthen cooperation and overcome the difficulties and seek common development of strategic vision, has a profound era background.

The data that Ministry of Commerce recently released sh ows, During the first quarter, China and the "The Belt and Road" along the country's bilateral trade amounted to 236 billion US dollars, accounting for $26 \%$ of the country's total import and export; Foreign investment. Our country has provided non-financial direct investment for the national which along "The Belt and Road" about $\$ 2.56$ billion in one quarter, accounted for $9.9 \%$ of the total amount of foreign direct investment at the same period. At the same time, at present our country is in "The Belt and Road" along the country, there are more than and 70 projects in the construction of the cooperation zone, construction area of enterprise infrastructure investment more than 8 billion U.S. dollars, will drive investment in the area of nearly $\$ 10$ billion.

Domestic financial institutions have been intending to participate, since the implementation of "The Belt and Road" strategy. From participating institutions, mainly divided into the Policy Banks, Commercial Banks and government backed funds, the policy banks involved in the "The Belt and Road" intensity is not small. "The Belt and Road" strategy need to move more private capital, The market of commercial banks and other financial institutions should play an active role in "The Belt and Road", and actively explore cooperation mode and innovation of financial investment bank, silk road fund, promote the policy finance and commercial finance cooperation.

\section{II. “THE BELT AND ROAD” StRATEGY TO BRING THE \\ OPPORTUNITIES FOR YUNNAN COMMERCIAL BANKING}

\section{A. The opportunities of geographical advantages to Yunnan commercial bank}

Yunnan has a unique geographical advantage, Yunnan north is connected with the Silk Road economy and southward to connect the maritime Silk Road, and it is the only one in China that can communicate with South East Asia and South Asia from the mainland, and connect to Europe and Africa through the Middle East. Yunnan through north and south of Asia Pan-Asia railway contact with Asian and European and other international channel on three continents, is the intersection of three oceans of the new Asia-Europe continental bridge linking hub. The unique geographical advantages, highlight the status of Yunnan in the "The Belt and Road" construction.

\footnotetext{
* Corresponding author
} 


\section{B. Industry innovation requires financial support to the commercial banking industry in Yunnan to bring opportunities}

The implementation of the "The Belt and Road" strategy strengthen the connection of Yunnan and southeast Asia, South Asia countries, In this way, we can export some of the excess industrial exports, to realize the transfer of resources, to provide a new growth point for the economic development of Yunnan. Such as Yunnan will overcapacity industry transferred to Southeast Asia and South Asia. On the one hand, it can solve the problem of excess capacity in Yunnan, on the other hand, can also reduce the production costs, realize the core value of resources, because of overcapacity in industry has lost competitiveness in domestic, through transfer can enhance the product value, transfer out of the products get more value advantage. At the same time, this part of the product sales will bring a lot of international settlement of funds, which will give Yunnan's banking industry unlimited opportunities.

\section{The financial innovation brings to the commercial Banks in Yunnan opportunities}

The implementation of the "The Belt and Road" strategy requires a lot of money, and these funds by national finance support alone is not enough, So need financing, and rely on the traditional financing model can't get enough money, so you need to innovation of financing mode. Such as the current by China launched the Asian investment bank is financing innovation model, of course rely on financing innovation at the national level is conducive to the implementation of "The Belt and Road" strategy, Far from the need of all funds, in this case, it provides an opportunity for local financial institutions. Yunnan banks can compensate the lack of Asian investment bank and Silk Road Fund in a timely manner, and through constantly the existing banking product innovation, can bring unexpected benefits. Regional innovation brings to the banking industry in Yunnan on the financing of new opportunities. so the implementation of the strategy of "The Belt and Road" will inevitably drive the development of the regional innovation.

\section{Chinese enterprises "going out" and foreign enterprises "coming in" to bring opportunities to the commercial banks in Yunnan}

Bank internationalization is not only to follow enterprise internationalization strategy, and also have the effect of the guide enterprises to carry out international operation. When enterprises making foreign direct investment, they will face the information channel is not smooth, Due to the lack of understanding of the international rules and conventions, resulting in the increase of overseas operation cost; 'going out' enterprises in the initial stage, the lack of awareness of the foreign market, Due to the lack of understanding of international rules and practices and the country's investment targets, resulting in an increase in the cost of overseas operations, going out of the enterprise in the initial stage of the lack of foreign market awareness, The Chinese banks set up outside the business organizations, to be able to directly understand the local economic, cultural, political, legal environment and other specific circumstances, Grasp firsthand information, for the domestic enterprise customers to provide the necessary information needed for foreign investment and trade.

In the "The Belt and Road" initiative to promote, not only Chinese enterprises to accelerate the going out, but also have more companies came in. Bank of China in overseas business institutions carrying on all aspects of China's economic, policy and legal knowledge advantage, for local intentionally with China for economic exchanges between enterprises and individuals provide the required information. Foreign enterprises can be through the Bank of China's overseas branch of the investment consulting department, using bank networks and the domestic government agencies, chambers of Commerce, and related enterprises approached, looking for investment and trade opportunities. By making full use of domestic resources, including banks, financial strength, customer relations and brand influence and other advantages, boost the excellent foreign enterprises to come.

\section{E. Yunnan commercial bank to bring new growth opportunities}

With the marketization of interest rate, open private capital to enter and promote the Internet financial, Chinese banking financial institutions operating domestic competitive pressure, earnings growth space facing shrinking. Banks on the basis of local operations, by accelerating the expansion of overseas markets, especially in emerging markets, can increase the source of new profits. In Europe and the United States and other developed countries, the financial market is relatively saturated, to broaden the space is relatively small, "The Belt and Road" initiative in developing markets radiation with growth and development potential is very high, a broader market space. Especially in Yunnan as "The Belt and Road" strategy for radiation center of Southeast Asia and South Asia and Central Asia, brought hitherto unknown opportunities to the Bank of Yunnan.

\section{The ChALlEnges UNDER "The Belt AND RoAD" STRATEGY TO YUNNAN's BANKING INDUSTRY}

\section{A. Threats and challenges of political instability in some countries and the differences of Party's ideas}

Under the implementation of "The Belt and Road" strategy in Yunnan, a large number of enterprises will go abroad. This walks out patterns require commodity trading as a support, and in some countries bid mechanism construction of infrastructure projects. These projects need the corresponding of financial institutions for financial support. However, in some countries because of political instability and the difference of concept among different parties, "The Belt and Road" will bring huge political risk and threats to the economic transactions to the province.

\section{B. Lacking of innovation in Yunnan local commercial banks}

Trade flow needs the innovation of banking services. The implementation of the international trade must rely on sound financial support system, especially trading with foreign enterprises, there will be a variety of financing models, such as foreign loans, offshore settlement and foreign currency transactions. These transactions need the support of domestic banking service system, but at present, there are still many 
problems in China's banking system, for example, the international contracting project financing concept fall behind the service; the international project risk assessment is not enough, and so on. In addition, as Yunnan's commercial banks gradually expand their business to overseas, foreign trade and investment demand become diversification, which is needed to establish a sound system of overseas network.

\section{The challenges from the inadequate of infrastructure in Yunnan to the bank}

The implementation of the "The Belt and Road" strategy must be combined with the actual development of the domestic economy. Although China is in a critical period of economic restructuring entering a newly development time, but for the actual situation in Yunnan, the biggest problem is not excess of capacity, but the lack of infrastructure. Tourism is the main industrial in Yunnan, therefore, in the implementation of the "The Belt and Road" strategy, Yunnan banking industry and enterprises should be combined with the actual situation of Yunnan. We should choose some enterprises to move overseas selective, such as some of the excess capacity of enterprises, rather than invest abroad blindly just to avoid crowding out which will lead to industry "empty", ultimately we have to compensate for the loss. This is a completely waste of resources and funds.

\section{THE BETTER DEVELOPMENT OF BANKING INDUSTRY UNDER THE STRATEGY OF “THE BELT AND ROAD”}

\section{A. Construction of basic service capacity}

Strengthening the construction of basic service capacity of monetary market can provide a steady support for financial innovation of commercial banks. Under the "The Belt and Road", there are so many countries and regions who use small currency will face greater currency exchange and the exchange rate risk in enterprises overseas investment management. Proposing continued to increase the settlement and settlement, interbank demolition, currency exchange transactions, market pricing mechanism and other basic capacity building accelerates the establishment of cross-border RMB settlement system and business rules and regulations. Based on market supply and demand in a managed floating exchange rate system, promote innovation in exchange rate risk management tools.

\section{B. Loose relevant control policies}

Further relaxing the relevant regulatory policies enhances the ability of commercial banks to cross-border financial services. Compared with developed countries, China's commercial banks overseas institutions are still lacking. Encouraging to simplify commercial Banks set up branches and overseas mergers and acquisitions approved by the examination and approval procedures, Encourage the support of its business layout in countries and regions along the "The Belt and Road". At the same time, In order to encourage commercial banks to provide financing and guarantees for projects in the "The Belt and Road" region, loans to eligible project appropriately lower risk weighting, expand the indicators of short-term foreign debts of commercial Banks. Foreign contract guarantee risk and the special funds, such as preferential export buyer's credit support policy extended to joint-stock commercial Banks.

\section{Local currency of enterprises overseas financing}

Promoting cross-border RMB pilot policy under the capital account, promote enterprise overseas investment and financing of local currency. In the steady progress of the RMB capital account convertibility under the guidance of the policy, can focus on nurturing the currency denominated and settled cross-border claims, equity trading market. Thus to further enhance the activity of the offshore RMB market, Expand cross-border RMB two-way flow of channels for enterprises to provide financial support and protection of foreign investment and financial capital.

\section{CONCLUSION}

The "Belt and Road Initiative" strategy is the new measure and grand idea to realize the deepening reform of China's economy, and strengthen China's economy, regional economy and the world's economic integration. Yunnan, Asia's radiation center, its' banks should look to the world, Seize the opportunity, and innovative service means and methods. In order to have a better development, Yunnan should come up with more active competitive mechanism, more flexible business model, and more innovative products and services in the face of challenges.

\section{ACKNOWLEDGEMENT}

I took nearly two months to finish this paper. In paper writing process I was encountered numerous difficulties and obstacles. With the help of both my classmates and teachers, I could finish this paper. In particular, I would like to thank my mentor. Without his patiently guidance and help, selfless for me to make the modifications and improvements, my thesis couldn't final complete. At the same time, I would like to thank all the scholars quoted in this paper, if without the research results of these scholars to inspire and help, I will not be able to complete the final writing of this paper.

Gold can't be pure and man can't be perfect. Because of my academic level is limited, there are some deficiencies in the paper, I urge all teachers and students to criticize and correct!

\section{REFERENCE}

[1] B. Feng, "The Belt and Road is Chinese logic for global development," Beijing: China democracy and legal press, 2015.

[2] H.Hu, "Commercial banks' practice for fulfilling their social responsibilities," Chinese Finance, vol. 5, 2012, pp. 70-72.

[3] J.Q. Jiang, "The international path of ICBC," Chinese Finance, vol. 4, 2012, pp. 9-12

[4] K. Kang, "Interconnection and intercommunication" creates a new era of financial diplomacy," Economic Daily, vol. 5, 2014.

[5] K.Q. Li, "Some problems on deepening economic system reform," Factuality, vol. 9, pp. 2014,3-10

[6] H.L.Zhang, "Finance guidance and "The Belt and Road"," Financial Forum, vol. 4, 2015, pp. 8-14

[7] X.T. Yuan, " "The Belt and Road" is treated as a national strategy to analysis," Theory Monthly, vol. 11, 2014 
[8] L. Jin, “"The Belt and Road”: China's Marshall Plan,” Research on international issues, vol. 1, 2015.

[9] C.Y. Wang, "The layout of overseas market for "The belt and road," The financier, vol. 4, 2015, pp. 53-54

[10] L. Wang, "How to play an active role for bank credit in construction of "The Belt and Road"," Finance and Economics (Academic Edition), vol. 14, 2015, pp. 49-50

[11] M.N. Zhang, "To enhance the "The Belt and Road" strategic development level," Macro-economic management, 2015.
[12] K.L. Wang, "How to capture the business opportunities for small and medium enterprises in Chongqing under the background of "The Belt and Road," Modern commerce and trade industry, 2016.

[13] D.Y. Sun. The influence of the "The Belt and Road" to China, 2016.

[14] W.N. Qin. "Chinese - South cooperation opportunities and challenges under the "The Belt and Road"," 2016. 